\title{
Prediction of a design flood-discharge that caused sedimentation in the river mouth of Batang Anai
}

\author{
Mas Mera ${ }^{1, *}$, and Hendra Yuldi ${ }^{1}$ \\ ${ }^{1}$ Civil Engineering, University of Andalas, Padang
}

\begin{abstract}
Batang Anai is a river that crosses through four administrative regions in the West Sumatra Province with a catchment area of about $498 \mathrm{~km}^{2}$. The upstream is a steep topography because it is located in west part of the Marapi mount. While the middle and lower reaches are mild since in the lowlands. The flow empties into the Indian Ocean. These conditions make this river meandering in the middle and lower reaches. The river mouth is influenced by the tide in which resists sedimentation toward the ocean. As a result, the capacity of the river cross-section decreases which eventually causes flooding. In 2013, the lower reach was dredged. In 2015, however, the river mouth was covered back by sedimentation by two-meter height in some points. Bathymetry was measured before and after dredging. This study is conducted to determine a design flood-discharge that caused sedimentation based on the 2015 bathymetry data by simulation using the SMS software, i.e. the RMA2 module for modelling hydrodynamics and the SED2D module for modelling sedimentation. The attention is paid to see both flow patterns and sedimentation profiles. The model scenarios consider by either including or excluding the Batang Kandis flow. Batang Kandis is a tributary of Batang Anai which empties into near its river mouth. The design flood-discharges for simulation are varied according to the return periods of 2, 5, 10, 25 and 50 years. The bathymetry data used for simulation are the 2013 one after dredging. All the simulation results are then compared to the 2015 bathymetry data. The hydrodynamic model in which the Batang Kandis flow included gives velocities close to those from the field for all return periods. The results of the sediment model using the flood flow with a 5-year return period, that's Batang Anai is $1060 \mathrm{~m}^{3} / \mathrm{s}$ and Batang Kandis is $268.5 \mathrm{~m}^{3} / \mathrm{s}$, show that the sedimentation profiles are closed to the 2015 bathymetric measurement data.
\end{abstract}

\section{Introduction}

Batang Anai is a river that crosses through four administrative regions in West Sumatera Province with a catchment area of about $498 \mathrm{~km}^{2}$ [1-2]. They are Tanah Datar Regency, Padang Panjang City, Padang Pariaman Regency and Padang City. The upstream is located in west part of the Marapi mount. The upstream is a steep topography in the highlands (Tanah Datar and Padang Panjang), while the middle and the lower reaches are mild and located in the lowlands (Padang Pariaman and Padang). Finally the flow empties into the Indian Ocean ( $0^{\circ} 49^{\prime} 02.94$ " S $100^{\circ} 17$ ' 27.24" E). These conditions result a meandering river in the middle and lower reaches. The river mouth is influenced by the oceanographic conditions such as the tide in which resists sedimentation toward the ocean. The logical consequence due to this sedimentation is the capacity of the river cross-section decreasing in which eventually causes flooding. Figs. 1, 2, 3 show Batang Anai and Batang Kandis in 2006, 2014 and 2016 respectively. The intersection of Batang Anai dan Batang Kandis is about $0^{\circ} 48^{\prime} 56.06^{\prime \prime} \mathrm{S} 100^{\circ} 17^{\prime}$ 32.77" E.

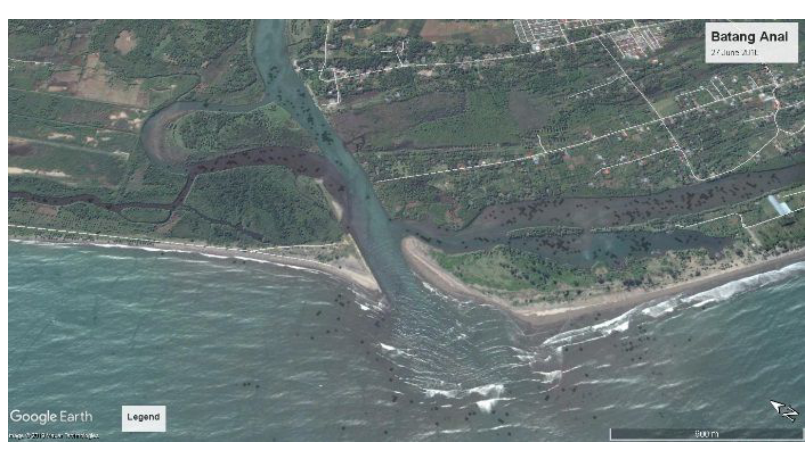

Fig. 1. Batang Anai and Batang Kandis in 2006 [4].

As a result, in 2001, a feasibility study to improve the flood control system was carried out on Batang Anai and Batang Kandis. This study covered the hydrology, hydraulics and coastal engineering. This study was conducted by the Indonesian Public Work Department in collaboration with Niken Consultant Japan [1-2]. The 2001 study was then followed up in 2013 by measuring bathymetry along the lower reaches of Batang Anai. The reaches was then dredged. In 2015, however, the river mouth was covered back by sedimentation by two-meter

\footnotetext{
* Corresponding author: mas mera@eng.unand.ac.id
} 
height in some points. Bathymetry was measured before and after dredging [3].

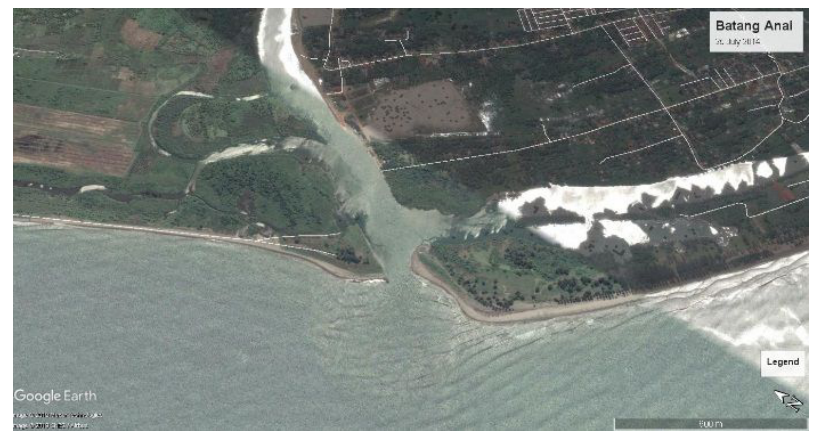

Fig. 2. Batang Anai and Batang Kandis in 2014 [4].

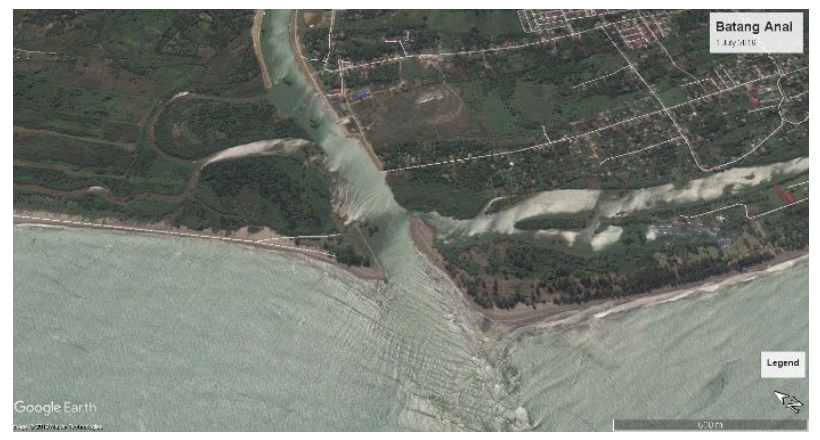

Fig. 3. Batang Anai and Batang Kandis in 2016 [4].

One of the most influential components when sedimentation increasing in a river mouth is the inability of the river flow to flush the sediment out. In this study, simulations of riverbed changes due to sedimentation in the river mouth of Batang Anai are carried out based on varied design flood-discharges. So that a design flooddischarge that significantly causes sedimentation until 2015 is obtained. Two modules in the SMS (surface-water modeling system) model, i.e. RMA2 and SED2D, are used in this study. The RMA2 module is used to simulate current hydrodynamics, and the SED2D module is used to simulate sediment transports. The simulations are carried out in the steady state condition. The riverbed profiles of the simulation results based on various design flooddischarges are then compared to bathymetry measurement data. Based on the comparisons will be obtained the magnitude of a design flood-discharge that is closest to the conditions causing sedimentation in the river mouth.

The SMS was initially developed by Engineering Computer Graphic Laboratory (later renamed to Environmental Modeling Research Laboratory or EMRL) at Brigham Young University in collaboration with U.S. Army Corps of Engineer Waterways Experiment Station (WES) and U.S. Federal Highway Administration (FHA). RMA2 is a two dimensional depth-averaged finite element hydrodynamic numerical model. It computes water surface elevations and horizontal velocity components for sub-critical, free surface flow in two dimensional flow fields. RMA2 computes a finite element solution of the Reynolds form of the Navier-Stokes equations for turbulent flows. Friction is calculated with the Manning's and Chezy equation, and eddy viscosity coefficients are used to define turbulence characteristic.
Both steady and unsteady (dynamic) problems can be predictsed. SED2D, formerly STUDH, is a two dimensional numerical model for depth-averaged transport of cohesive or representative grain size of noncohesive sediments and their deposition, erosion, and formation of bed deposits [5].

Several previous studies have shown that SMS software has been used to describe the hydrodynamics and currents in several regions. Liu et al. for example, they modified the 2D hydrodynamic model based on average velocities by including the effect of mangroves on flow resistance described by empirical equations depending on water depth and resistance coefficient. This modified model is verified using physical modelling data. The validation results showed a fairly good match. The model was then applied to the entire Tanshui River system that was affected by tidal waves by including mangroves near the mouth of the Keelung River. The results of this scenario showed that the modified model can be used as a basis for mangrove management [6]. Mwanuzi and Vanacher conducted a study of sedimentation and management of the catchment area. In their study, two SMS modules (RMA2 and SED2D) were used to simulate river flow and to predict sediment transport and deposition in Simiyu River, Tanzania. The SMS model results were compared to those of other model, that is SCALDIS model developed at the Free University of Brussels. Both numerical models contain a twodimensional hydrodynamic module and a sediment transport module, allowing simulation of stream flow and sediment transport processes in river channels. However, they differ in the following aspects: the sediment transport model in SMS is decoupled from the hydrodynamic module while SCALDIS is coupled model where the hydrodynamic and transport are run in the same time. The comparison of the results of both models indicates that SCALDIS is easier to calibrate as compared to SMS. The SMS modules require detailed information about a large number of model parameters, which is difficult to obtain in remote areas. The SCALDIS model is less input demanding, and only the sensitive parameter is the Manning's coefficient, which can be estimated based on expert knowledge and limited field measurements. [7]. In 2013, sediment transport in Simiyu River was investigated by Griensven et al. using the hydrologic model, Soil and Water Assessment Tool (SWAT) and the 1D hydrodynamic simulation software for Rivers and Estuaries (SOBEK-RE) model. Routing in SWAT is completed using the simplified Bagnold's equation and in the SOBEK-RE model is undertaken using the Saint Venant equation. When comparing the results of both models for the different reaches of the main channel and main tributaries, both models showed different results both in magnitude and in sign (erosion/deposition). However, in a situation where data is scarce (such as grain size, channel geometry), the more complex hydrodynamic model does not necessarily lead to more reliable results [8]. Gad et al. formulated a simplified multi-component technique for modelling the 2D sediment transport in the vicinity of navigation channels to harbours. The technique requires the application of three numerical models: NMLONG model (1D depth-averaged finite difference 
wave model), RMA2 (2D depth-averaged finite element hydrodynamic model) and SED2D (2D depth-averaged finite element sediment transport model). RMA2 is forced at the inflow boundary using the longshore velocity profiles generated by the incoming waves via the application of NMLONG model. Output of NMLONG provides also the boundary condition of SED2D which takes a velocity field input from RMA2. A variable manning coefficient is used inside RMA2 domain to account for wave roughness. Data collected in the period from 1989 to 1997 in the vicinity of the navigation channel of Damietta Harbour (Egypt) were used to calibrate the multi-component technique. The results showed that the technique explains well the observed spatial variation of bed change in the navigation channel. The calibrated technique was then applied to study different solutions to reduce sedimentation in the navigation channel of Damietta Harbour. The results showed that the optimum solution found can significantly reduce the amount of sedimentation [9].

\section{Methodology}

Numerical simulations are carried out by combining varied design flood-discharges and either joining or not joining Batang Kandis to Batang Anai. The design flooddischarges consist of five various return periods, i.e. 2, 5, 10, 25 and 50 year periods. These design flood-discharges were predicted by the Indonesian Public Work Department [3]. As a result, ten scenarios are obtained. The first scenario is the design flood-discharge with a 2year return period of $1024 \mathrm{~m}^{3} / \mathrm{s}$ (excluding Batang Kandis). The second scenario is the discharge with a 2year return period of $1024+246.6 \mathrm{~m}^{3} / \mathrm{s}$ (including Batang Kandis). Other scenarios can be seen in Table 1.

Table 1. Simulation scenarios.

\begin{tabular}{|c|c|c|c|}
\hline \multirow{2}{*}{ Scenarios } & \multirow{2}{*}{$\begin{array}{c}\text { Return Periods } \\
\text { (years) }\end{array}$} & \multicolumn{2}{|c|}{ Discharges $\left(\mathrm{m}^{3} / \mathrm{s}\right)$} \\
\hline & & Batang Anai & Batang Kandis \\
\hline 1 & 2 & 1024.0 & \\
\hline 2 & 2 & 1024.0 & 246.6 \\
\hline 3 & 5 & 1060.0 & \\
\hline 4 & 5 & 1060.0 & 268.5 \\
\hline 5 & 10 & 1120.0 & \\
\hline 6 & 10 & 1120.0 & 305.0 \\
\hline 7 & 25 & 1300.0 & \\
\hline 8 & 25 & 1300.0 & 415.0 \\
\hline 9 & 50 & 1600.0 & \\
\hline 10 & 50 & 1600.0 & 597.5 \\
\hline
\end{tabular}

The computational domain is from the river mouth of Batang Anai up to 1000 meters towards the upper reaches of Batang Anai. The boundary conditions in the upstream are the discharges of Batang Anai and Batang Kandis, while in the downstream is the water surface elevation. The computational domain and boundary conditions can be seen in Fig 4. The triangle meshes are made using GFGEN module of SMS.

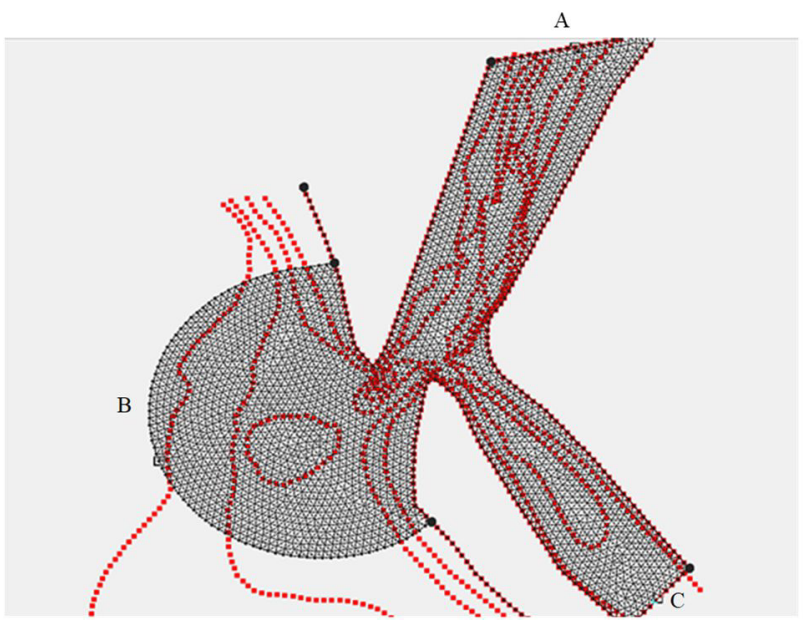

Fig. 4. Computational domain and boundary conditions: A indicates Batang Anai Flow; B indicates water surface elevation; and C indicates Batang Kandis flow. Dash lines indicate contour lines.

All simulation scenarios are carried out in two stages, namely the flow simulation stage using various the design flood-discharges, and then proceed with the sediment simulation stage. The output from the flow simulation stage is validated with field data, prior to be used to simulate the sediment transports. The sedimentation pattern due to sediment simulation is characterised by the formation of a new bathymetry. All patterns are then compared to the measured bathymetry in the field. From the 10 simulation scenarios that will be done, it will be obtained the closest scenario results to the field conditions. If the scenario results closest to the field conditions are obtained, then the design flood-discharge is obtained too.

\section{Results and Discussions}

Verification between the simulation results of the current velocity (RMA2) is done by matching them with the field conditions, i.e. data from the measurement of current velocity. These measurement data are obtained from observations for the return period of 2 years to 50 years done by Kemen PU [3]. The comparison of simulation and measurement results shows that all results of scenario simulations with the Batang Kandis included are close to the observation results (Fig 5). Both results show good agreement, so that the model can be used to simulate the sediment process in the river mouth. However, the simulations excluding the Batang Kandis flows do not show good agreements between the model results and the measurements. Consequently, all scenarios by ignoring Batang Kandis flow are not simulated any more. In other words, the next simulations for sediment transports will be five scenarios only, i.e. scenario 2, 4, 6, 8 and scenario 10 . 
The SED2D simulation results in the form of new bathymetry due to sediment movement. To predict the design flood-discharge that caused sedimentation in the river mouth, the model results are then validated by comparing the model results to the measured bathymetry. There are 4 sections of observation, namely Section 1-1, Section 2-2, Section 3-3, and Section 4-4 as shown in Fig. 6.

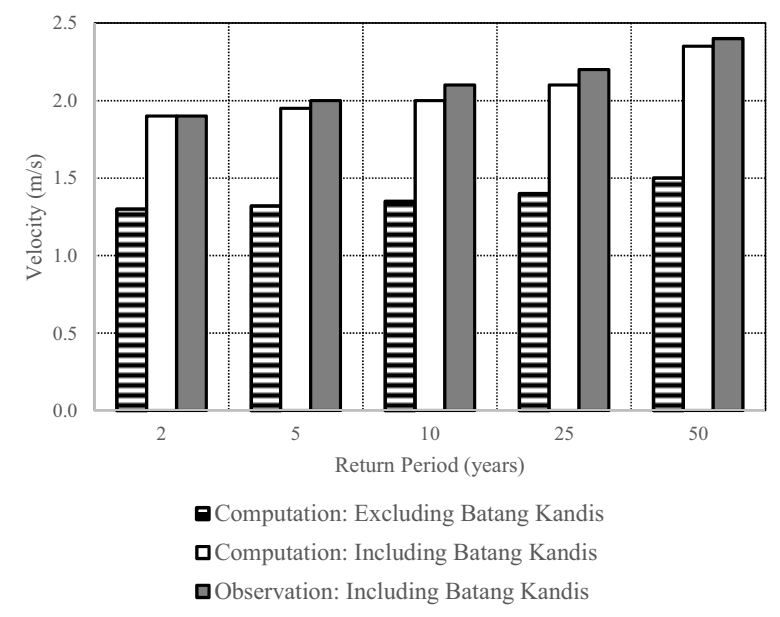

Fig. 5. The comparison between the model computational and measured velocities.

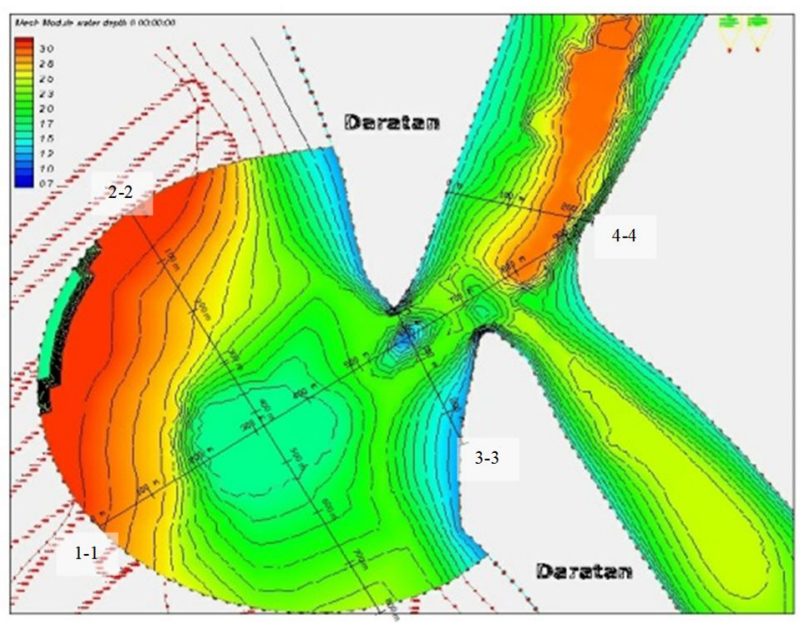

The simulation results based on the second scenario (with a 2-year return period, discharge of Batang Anai is $1024 \mathrm{~m}^{3} / \mathrm{s}$ and discharge of Batang Kandis is $246.6 \mathrm{~m}^{3} / \mathrm{s}$ ) shows a significant sedimentation process in the river mouth. Sedimentation is seen in Sections 1-1 (Fig. 7 and 8) and Section 3-3 (Fig. 10), while in Sections 4-4 (Fig. 11) the river bed tends to be deeper. This condition occurs probably due to the velocity in the river mouth relatively slow.

Simulation using the design flood-discharge with a 5year return period, i.e. the fourth scenario (Batang Anai discharge is $1060 \mathrm{~m}^{3} / \mathrm{s}$ and Batang Kandis discharge is $268.5 \mathrm{~m}^{3} / \mathrm{s}$ ) shows the similar pattern as shown those using the design flood-discharges with a 2-year return period. Sediment accumulation occurs in the river mouth, but the riverbed in Section 3-3 deepens (Fig. 10).

The next simulation is to simulate the sediment concentration with a 10 -year return period, which is the sixth scenario (Batang Anai discharge is $1120 \mathrm{~m}^{3} / \mathrm{s}$ and Batang Kandis discharge is $305 \mathrm{~m}^{3} / \mathrm{s}$ ) which shows an increase in sediment distribution in Section 4-4 (Fig. 11). Meanwhile, Sections 1-1, 2-2 and 3-3 (Fig. 7 to 9) indicate that the depth of the riverbed tends to increase. The sixth and the eighth scenario results give the similar patterns, as a results the sixth scenario results are not showed in Sections 2-2, 3-3 and 4-4.

The simulation based on the discharge with a 25-year return period or eighth scenario (Batang Anai discharge is $1300 \mathrm{~m}^{3} / \mathrm{s}$ and Batang Kandis discharge is $415 \mathrm{~m}^{3} / \mathrm{s}$ ) shows the result of a decline in the riverbed. This situation occurs in all sections (Sections 1-1 to 4-4).

The simulation based on the discharge with a 50-year return period or tenth scenario (Batang Anai discharge is $1600 \mathrm{~m}^{3} / \mathrm{s}$ and Batang Kandis discharge is $597.5 \mathrm{~m}^{3} / \mathrm{s}$ ) shows that sediment concentration occurs in the river mouth and in front of it (Sections 2-2 and 3-3) so as to form a bar, while in Section 4-4 the river channel tends to be deeper.

Fig. 6. Observation sections.

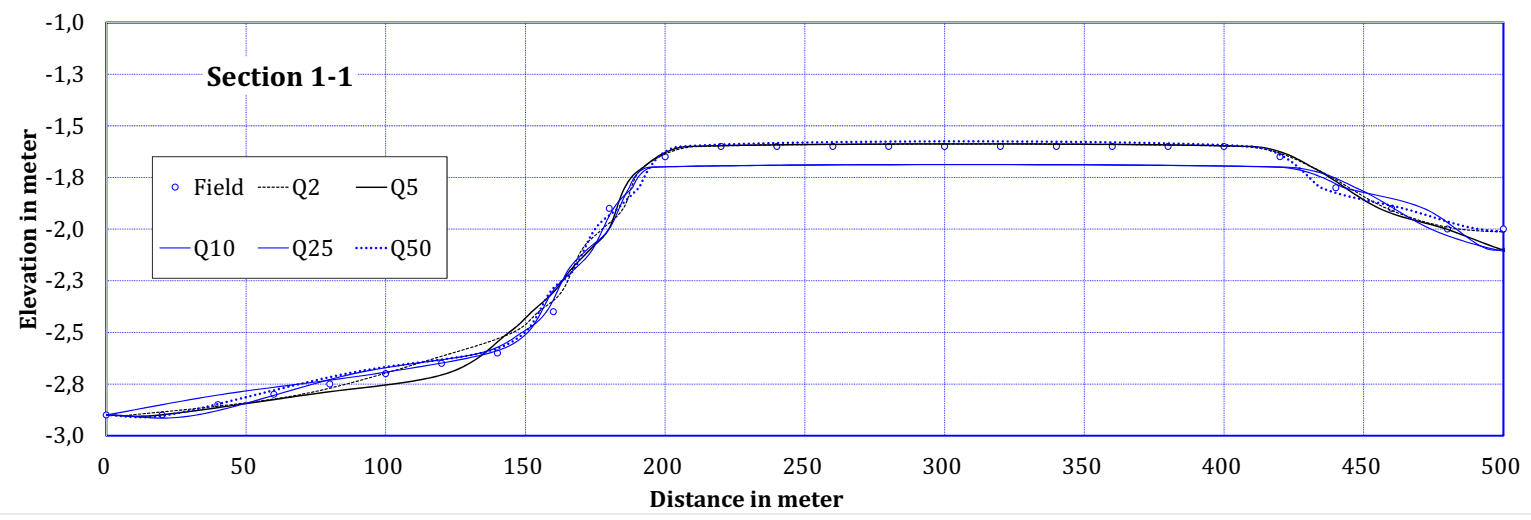

Fig. 7. Section 1-1 (0 to $500 \mathrm{~m})$. 


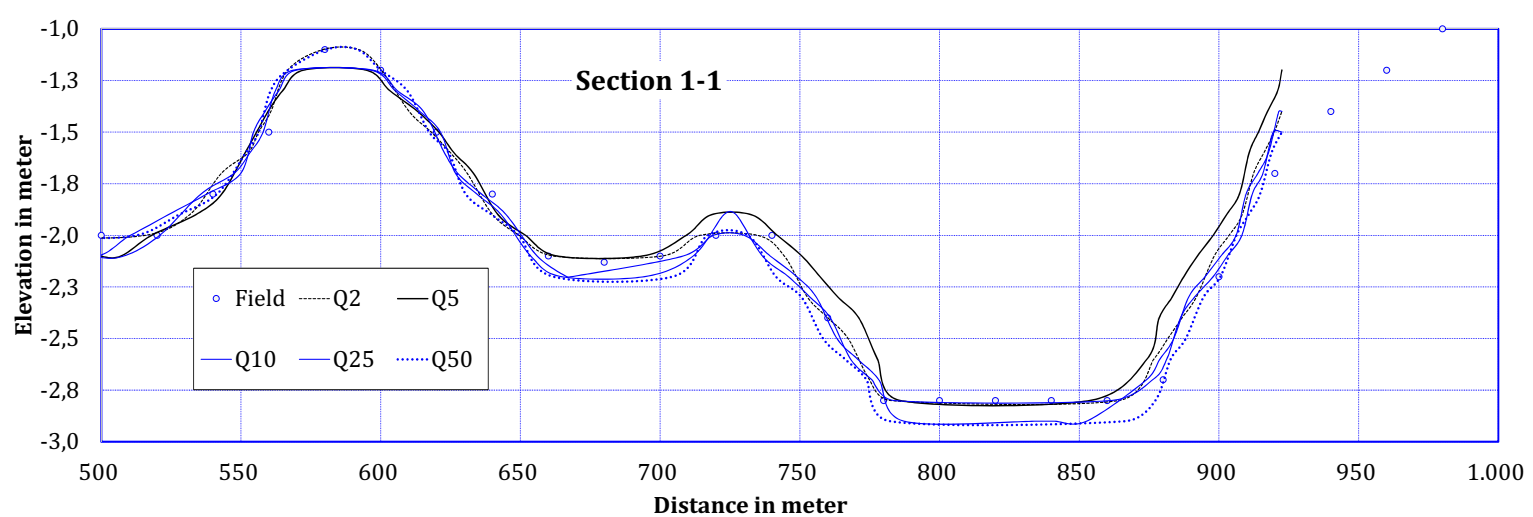

Fig. 8. Section 1-1 (500 to $1000 \mathrm{~m})$.

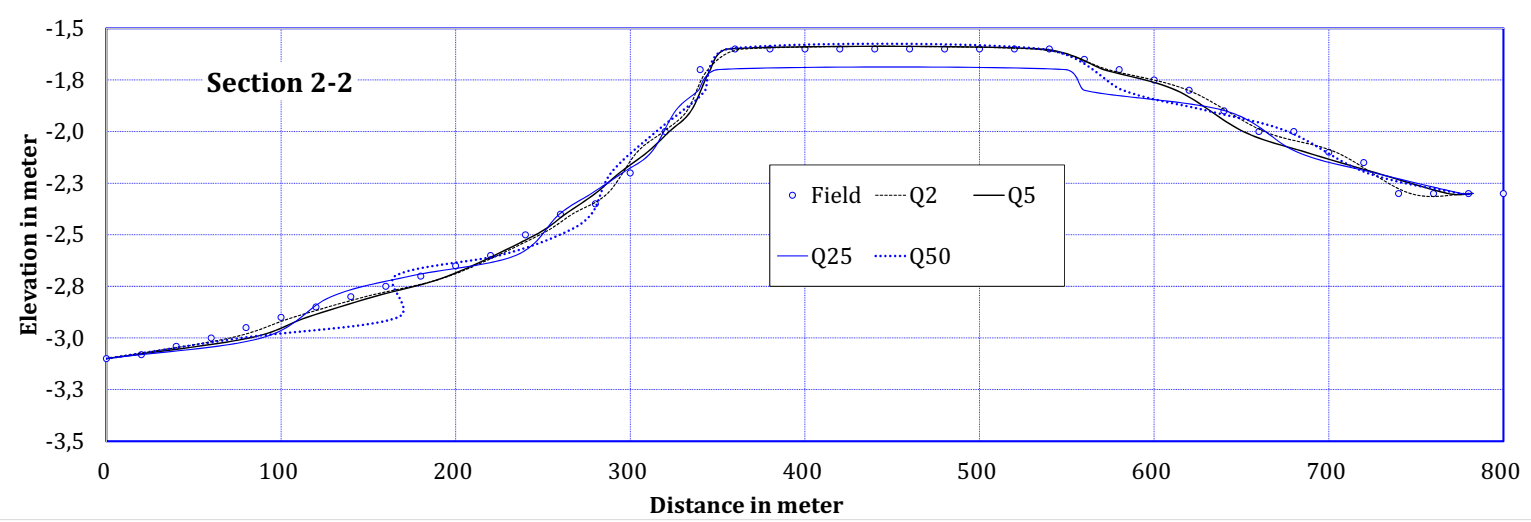

Fig. 9. Section 2-2 (0 to $800 \mathrm{~m})$.

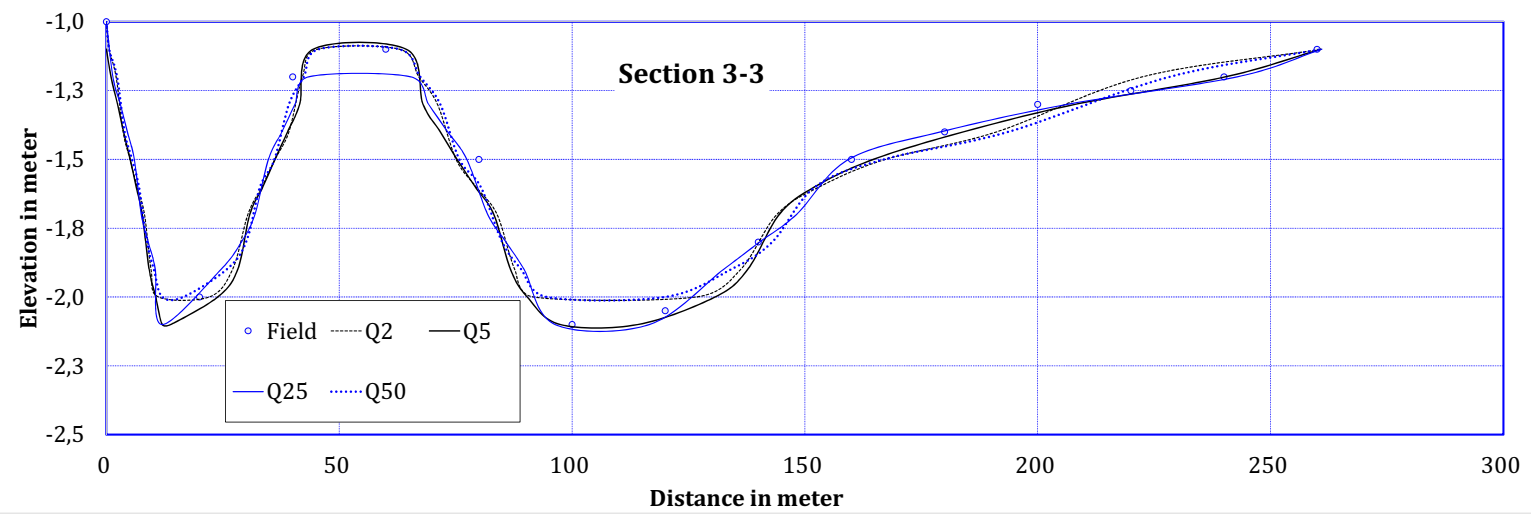

Fig. 10. Section 3-3 (0 to $300 \mathrm{~m}$ ).

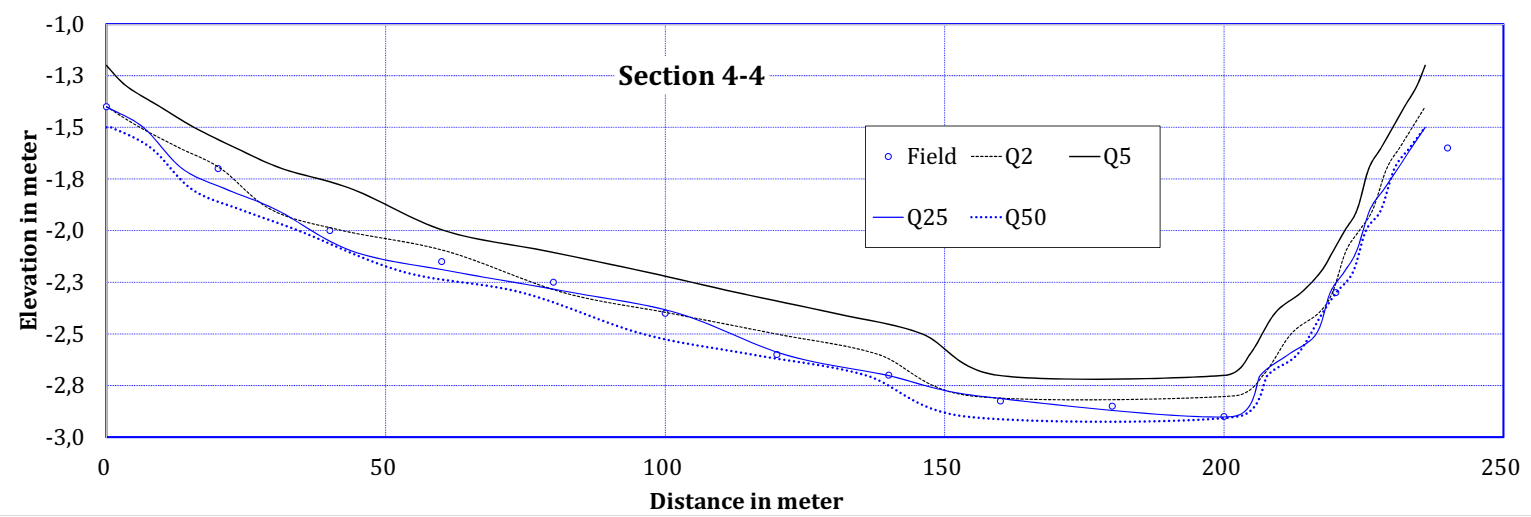

Fig. 11. Section 4-4 (0 to $250 \mathrm{~m})$. 


\section{Conclusions}

All simulations using the hydrodynamic model (RMA2 module) show that the current velocity that is close to the measurement are all scenarios with the Batang Kandis flows included. Consequently, all scenarios with Batang Kandis flows excluded are not performed in the sediment simulations. All sediment simulations using the sediment transport model (SED2D module) with various return periods, indicate that the sedimentation profiles that are close to bathymetry in the field are a simulation using a 5year return period (Fig. 12).

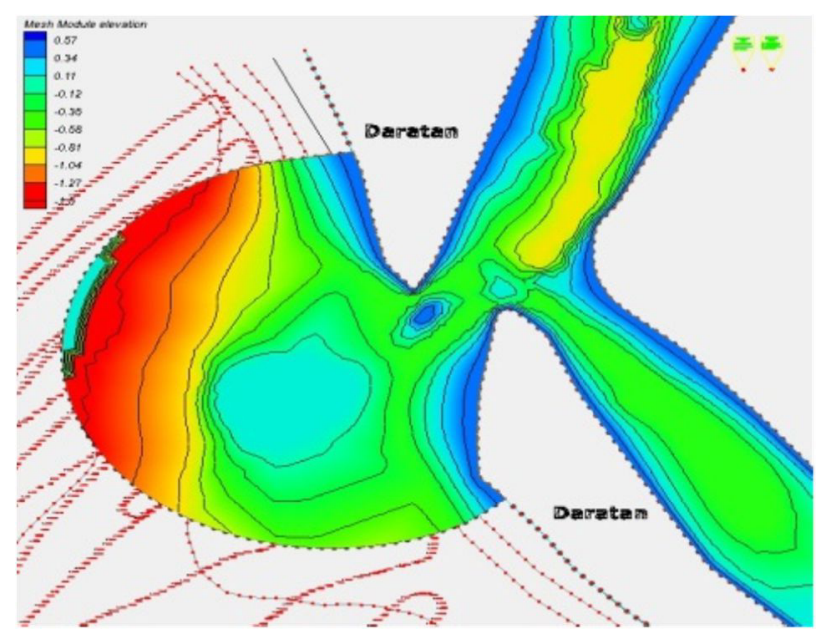

Fig. 12. New bathymetry due to the simulation based on the design flood-discharge with a 5-year return period.

\section{References}

1.Kemen PU, Anai-Kandis River Urban Flood Control System Improvement. Appendix D, Hydrological/Hydraulic Study, II. Kementerian Pekerjaan Umum dan Nikken Cons. (2001)

2.Kemen PU, Anai-Kandis River Urban Flood Control System Improvement. Appendix I: Coastal Study, V. Kementerian Pekerjaan Umum dan Nikken Cons. (2001)

3. Kemen PU, River Improvement of Lower Reaches of Anai River, Padang Sub Project. Shop Drawing, Kementerian Pekerjaan Umum dan Engineering, Yachiyo JICA Loan IP -551 (2015)

4. GoogleEarthPro, https://www.google.com/earth/versions/,

5. Aquaveo, SMS User Manual (v11.1), http://www.aquaveo.com (2013)

6. W-C. Liu, M-H Hsu and C-F. Wang. J. of Waterway, Port, Coastal and Ocean Engg 129(2), 86-92 (2003)

7.F. Mwanuzi and V. Vanacher. J. of the Res. of a Study Conducted by the Friend/Nile Research Component on Sediment and Watershed Management (2006)

8. A-v. Griensven, I. Popescu, M.R. Abdelhamid, P.M. Ndomba, L. Beevers and G.D. Betrie. Phy. Chem. of the Earth, Parts $A / B / C$ 61-62 12-21 (2013)

9. M.A. Gad, A. Saad, El-fiky and M. Khaled. Coastal Engg J. 55(2), (2013) 